\title{
Massifying Stem Education in Africa
}

\author{
Dr. Kehdinga George Formunyam \\ Teaching and Learning Development Centre, \\ Mangosuthu University of Technology, \\ South Africa. \\ Orcid id: 0000-0003-2510-3498.
}

\begin{abstract}
The world is on the brink of a technological revolution, which will change the way of life as we know it. This study identifies science, technology, engineering, and mathematics (STEM) education, as a valid response from the educational sector to these global changes. There are a plethora of comparative indicators, which illustrates how Africa lags behind other continents of the world, in scientific productivity and knowledge systems. This study proposes the massification of STEM education as a countermeasure, to enable Africa meet up with the global competition, and prepare for the future. Massifying STEM education in Africa involves creating access via several strategies, resulting in the increase of student enrollment in STEM fields. This paper concludes that massifying STEM education boarders on creating access, ensuring quality and relevance of STEM education across Africa. Recommendations made include the active involvement of all stakeholders in promoting STEM fields, and the availability of STEM education across all age groups, and gender in Africa.
\end{abstract}

Keywords: Massification, STEM education, masssify, STEM

\section{INTRODUCTION AND PROBLEM}

The world is on the brink of a technological revolution, which will change the way of life as we know it. Technology in the works span everything from boosting security with biometric data, improving in-store retail experiences, disease diagnosis, self-driving cars, renewable energy, voice-activated assistance, and software that can trade and invest (WEF, 2016; Lapierre, 2018). The education sector has not been exempted, as new teaching and learning solutions are currently being tested globally. As stated by WEF (2018), five trends will impact the world, and they are all technologically related. These trends include advances in mobile Internet, advances in cloud technology, increase in the availability of big data, increase in the adoption of new technology, and advances in artificial intelligence. 75 million jobs will be lost, but will be replaced with 133 million new jobs, available only to technologically inclined employees. The world is currently focused on technological innovations, and high technology research and development. These have been projected to be the future, and have become key drivers of the economy (McGuiness, 2018).

A valid response from the educational sector on these global changes, should involve the training of creative minds, to develop capacity in the rapidly emerging areas in science and technology. Global institutions of learning are realigning focus, and have intensified the training of scholars in Science, Technology, Engineering, and Mathematics (STEM) fields. Africa should take cue and prepare its populace for a future driven by technology, ensuring that the continent emerges as a global competitor (Penprase, 2018). Currently, there are a plethora of comparative indicators, which illustrate how Africa lags behind other continents of the world, in scientific productivity and knowledge systems. Ranging from challenges with educational infrastructure, to curriculum structure and inadequate funding, educational institutions in Africa are not fully geared up to develop STEM capabilities on the continent. Despite subsidising public education by most African governments, Khumbah (2018) writes that "Africa's current stock of graduates with secondary and tertiary level skills is still highly skewed towards the humanities and social sciences, while the proportion of students in STEM averages less than 25\%". These issues have led to the inadequacy of competent domestic STEM workforce in the continent, thereby adversely affecting Africa's position as a global competitor today, and in the future.

Responding to these issues, this study proposes the massifcation of STEM education in Africa, as a panacea to enable Africa compete globally. There is a shortage of skills in specific STEM areas such as engineering and technology, which has affected the capacity of the continent to grow and develop (African Union, 2014). Africa as a region is inadequate in engineering and technology, and this is evident in its slow, conservative, and manual process of getting things done. A report by the World Bank in 2014 maintain that, universities in Africa have made considerable progress in the amount and depth of their research in STEM subjects, but the continent still lags behind in innovation in science and technology (World Bank, 2014; UN, 2016). With this deficiency in innovative science and technology, the pace of progress in the region will be inauspicious. Massifying STEM education in Africa is expected to encourage African students on all levels, to major in Science, Technology, Engineering, 
and Mathematics fields. This approach proposes to improve the eventual output of technologically inclined graduates, leading to the growth of a more skill-intensive, and diversified African economy. To this end, the first part of this paper will discuss STEM education, while exploring the concept of massifcation in education. The second part will expose the challenges currently hindering the promotion of STEM fields in Africa, further proffering solutions for the transformation of STEM education in Africa, through massifcation.

\section{THE CONCEPT OF STEM EDUCATION AND IT'S IMPERATIVE FOR AFRICA: REVIEW OF LITERATURE}

The fields of Science, Technology, Engineering, and Mathematics (STEM) have been globally identified as priority, as it is in the heart of our fast moving technologydriven world. These fields are individually significant and can be taught in isolation, but the fusion of all four fields has become a global phenomenon. McDonalds (2016) supports this view stating that when these fields are collectively applied, they can deepen understanding, and solve real world problems. STEM fields improve human understanding of the physical human environment, support research, and encourage experimentation. Blurring the boundaries among these individual disciplines, STEM education presents an integrated approach to solving real world problems, using combined knowledge from two or more of these fields. STEM education is defined differently by different groups and people, but there is a consensus on its positive results. Xie et al. (2015) postulates that STEM education is the purposeful integration of the Science, Technology, Engineering, and Mathematics disciplines, with the objective of solving real life world situations. Siekmann \& Korbel (2016) argues that its objective is to expand the abilities of students, by supporting technical and scientific education, with a strong emphasis on critical and creative thinking skills. As an integrative approach to curriculum and instruction, STEM education grooms students to solve new problems, and draw conclusions based on previously learned principles applied through STEM. Utilizing inquiry-based and problem-based instruction approach, STEM education develops creative minds that produce solutions to real life issues through creativity, critical thinking, communication, and collaboration skills.

For Africa, reliance on an infinite wealth from the limitless creativity and talents of its teeming population will generate economic value, and promote the adaptation of its education sector to the growing trends of this digital era. Creating a knowledge-based economy through STEM education is a lifeline for the continent, ensuring the growth of a STEM capable citizenry. An average African individual can then generate new ideas, possess conceptual understanding on STEM issues, and critical thinking skills needed to solve most of the pressing challenges facing the continent in all sectors (Schilero, 2013). There is a need for STEM education because it has been hypothesized as a solution to depressed economies (Williams, 2011). Taking a retrospective look at some events such as the economic depression in the 1890s, 1930s and 1980s, the lack of promotion of technology education had a lot to do with it (Williams, 2011). With rapid technology development in the order of STEM education, there will be a change in the conduct of events generally, especially in production. This will be expected to lead to the development of the economy, thereby containing depression. Technological development is vital for economic growth as manifested in the highly industrialized nations. Reliance on the crude old methods of production has made Africa to take a back sit in all indices of development, hence the need to have STEM education as a panacea to depressed economies. Consequently, the penchant to keep abreast with latest technology will come to the fore, driving competition in the global space (Iksan, 2009). With massive industrialization in Asian countries facilitated by reliance on technology, other economies naturally seek to replicate such in their respective countries, with the expectation of improving the standard of living of their citizens. Past educational structures in Africa did not factor current realities into its focus, leading to the production of skill deficient African students. Promoting STEM education in the African education space will ensure that, emphasis is laid on recent global events that affect the biodiversity in the ecosystem, resulting in the review of the curriculum. For example, Burnett \& Jayaram, (2012) reveal that skills taught in the Middle East and North Africa, do not align with the needs of employers, causing a wide unemployment gap in those economies. This exposes the need for synergy, ensuring that what is taught in educational institutions in country addresses the challenges facing its populace.. Widespread development in information, communication and technology (ICT), has led to the automation of several processes in this sector, costing workers who are tech deficient their jobs. (Voogt \& Roblin, 2012). To be a part of the future, there is need for developing STEM education in Africa, especially since manual based processes are still prominent. The world is gravitating towards a seamless technology based scene, which may lead to the exemption of most African countries on the global front if necessary changes are not made. STEM education is therefore vital for an overall development in Africa. There is also a need for a holistic and multidisciplinary approach, in order to record apposite development in Africa, necessitating the focus on STEM education. In STEM education, students apply principles of science, technology, engineering and mathematics to combat challenges, which typifies the multidisciplinary approach of STEM education (Chalmers et al, 2017). The aim of STEM education is to have an integrative approach to solving real life issues with the use of technology (Sanders, 2008). These are issues that span all sectors, creating alternative solutions to energy, health, and environmental issues amongst others (Durik et al, 2015: Kennedy \& Odell, 2014). Some of these issues arose as a result of Africa's growing population, leading to the unavailability and inadequacy of required resources. Training STEM experts will encourage the development of groundbreaking technologies to tackle these issues, and present the possibilities of economic growth, and global competitiveness. Although education in Africa has improved as more children are enrolled to get an education as required, there is a challenge of lack of interest in STEM subjects for various reasons. More arts graduates are churned out yearly 
with no background knowledge of STEM fields, which has become pertinent to survival in the future. Kigotho (2019) asserts that students' enrolment in universities rose from 2.5 million in 2000 , to 7.4 million in 2015 in sub-Saharan Africa but, higher education students enrolled in STEM programmes in West Africa is still as low as 9\%. There is no question that the enrolment of African students into STEM fields needs to increase, especially if Africa aims at repositioning itself to becoming a dominant player in the global arena. This study therefore proposes an institutional massification of STEM education, as a strategy to improving Africa's position in a globally competitive knowledge economy.

\section{UNDERSTANDING MASSIFICATION OF STEM EDUCATION}

Richard (2016) postulates that massification is the mass adaptation of a phenomenon, by the suppression of its distinguishing features. Massification came to the lime light after the World War II in Europe and America, when there was a need for religious groups to control the society and record numbers (Srikanthan, ND; Wilson, 1996; GuriRosenblit \& Sebkova, 2004; Trow 1974; Guri-Rosenblit, Sebkova \& Teichler 2007). Scott (1995) used the term massification in the context of higher education, while describing rapid increment in student's enrollment around the latter part of the twentieth century. This implies that massification is about increase in quantitative terms as opined by the author. Mohamedbhai (2014) conceptualized institutional massification as an average annual increase in enrolment of about $15 \%$, to $25 \%$ over a decade. Mohamedbhai's definition stems from Martin Trow's categorization of the higher education system, in his bid to explain massification. Based on Gross enrolment rates, Trow divided higher education systems into three categories in 1973. The first is called the elite higher education system, which enrolls less than $15 \%$ of students within the age of 18 24 years. Elite level of massification of higher education is premised on influencing and shaping the mind and character of the ruling class, making them ready for elite duties. This is confined to the ruling class, as they are well prepared to take up elite and leadership roles. The second category is the mass higher education system which enrolls from $16 \%$, to $50 \%$ of the same age group. This level of massification is the dissipation of skills, and preparation for a broader range of technical and economic roles necessary for economic development. The third is the universal higher education system which enrolls over 50\%. The universal level of massification is concerned with the adaptation of the whole population, to rapid changes in social and technological structures of the society (Trow, 2006).

Drawing from this classification, massification can be defined as the rapid increase in student enrollment, causing a transition from the elite, to mass higher education. According to Hornsby \& Osman (2014), this increase in enrollment results from evidence linked to improved health system, economic development, empowerment, and the democratization of education. Massification challenges the traditional form of higher institutions of learning, as centers of elite education available only to a selected few. In Africa, massification came to the fore after independence, when nations chose to upgrade the social and economic development of their citizens (Kariwo, Gounko \& Nungu, 2014). This was in response to historical conditions leading to institutions enrolling students in excess of their capacity. Africa experienced a dramatic escalation in the demand for education, resulting in the expansion of primary and secondary enrollment, and output. South Africa recorded a 60\% increase in student enrolment between 1996 and 2011, from 590,000 to 938,000(MacGregor, 2014). In Kenya, massification started in 1990 s, leading to the double intake of students from form four, including graduants from form six. This propelled the government to create several universities, and recognize several private universities, with the aim of increasing the absorption of students from secondary school, to the university. This was done in anticipation that it will translate into increasing high skilled manpower, vital for economic development (Republic of Kenya, 1988).

Massifying STEM education in Africa therefore involves creating access via several strategies, resulting in the increase of student enrolment into the fields of Science, Technology, Engineering, and Mathematics. Enrollments into STEM fields are currently low, testifying to the elite nature of STEM education in Africa due to several factors, continuously hindering the full participation of the African populace in STEM fields despite the prospects. For one, the use of English language as the language of instruction for STEM subjects affects the interests of learners in these fields. Not only does it exempt a lot of Africans who are not familiar with the language, it discourages contribution from its mass population as learning and understanding is seemingly difficult. Another issue is the exemption of children from STEM fields until much later in their teenage age. Most Africans do not encounter these STEM subjects until secondary school, and this affect their interest in these fields. Access and participation in STEM fields should be broadened, and made available to all Africans across all age groups regardless of gender. There is a perceived notion that women do not do well in Science and Technology fields, and this also has it effects on the issue of access. The low proportion of women in science is due to low enrollments at the primary level, failures of retention, and lack of mentors and models to motivate aspiring female scientists at the higher levels. Tunisia is the only African country with about $47 \%$ of women represented in their scientific research workforce. This is compared to $8 \%$ obtainable in Togo and Burkina Faso. Studies reveal that no West African country has reached the $25 \%$ mark for women in science ( Okeke et al. 2017; Khumbah, 2018; \& BabaciWilhite et al. 2016).

While some developed nations dedicate as much as $4 \%$ of their GDP in scientific research, African governments do not value investments in scientific research and development. This affects the progress of these institutions as they become static, lacking in valuable contributions to the fields of STEM. Furthermore, Africa lacks well trained STEM teachers to provide the skills needed to build and innovate in STEM fields. This discourages learners as interest is lost due to the 
unattractive nature of the teaching and learning process under these unqualified tutors. The number of qualified STEM faculties in most African countries has remained static, or declined due to brain drain. These institutions are then staffed by underqualified teachers who are incapable of handling STEM portfolios. Africa has also continued to fail to rebalance its educational offerings from humanities and social sciences towards STEM subjects. It therefore needs to make up for long delays in developing STEM capabilities on the continent (Khumbah, 2018). Governments in Africa have to revitalize their education system towards STEM education, making it the pivotal frontier in the continents historical evolution. This is because the relevance of other sectors and institutions in the African economy will be directly dependent on the caliber of its STEM graduates (Okeke et al. 2017; Khumbah, 2018; \& Babaci-Wilhite et al. 2016).

\section{WHY IS THERE A NEED TO MASSIFY STEM EDUCATION IN AFRICA?}

There are more than a billion people in Africa, and unfortunately, there are only 2000 colleges and universities (Phillip L Clay, 2016). This value in terms of the number of colleges and universities, in comparison to the total population in Africa is discouraging. To have the sustainable future that Africa desires, there is a need to massify STEM education in Africa. In Sub-Saharan Africa for example, seventy percent of the population is under 30, but only $7 \%$ of Africans enroll in tertiary institutions (Sarah Boumphrey, 2016: Fred Swanike, 2016). This implies that the bulk of the population is within the youth demography, and there is low enrollment in tertiary education in Africa. Rapid increment in student's enrollment is therefore important in the field of STEM in the African continent. With Africa being a region with great prospect that can result in economic growth and prosperity, skill shortage in vital sectors may hamper the realization of economic prosperity in Africa. Speaking at a pan African conference on education, Firmin Matoko(a director general with UNESCO), states that it is imperative for Africa to tap into scientific inventions and discoveries that are globally popular, by increasing investments in scientific research. This will elevate Africans from the level of consumers, to producers of relevant technological knowledge.

Curtailing the brain drain and migration of highly qualified Africans to other developed nations of the world necessitates the massification of STEM education. As revealed by UNESCO, if Africa will achieve the 2030 goal of quality education for its citizens, 19.6million trained teachers are needed by 2030. This implies that Africa needs at least 1.2 million trained teachers annually, particularly because it has one of the fastest growing school age population globally. With above $60 \%$ of the entire population below 25, it makes the continent the world's youngest region today, and by 2030 , it has been presaged that it will be the base of more than onequarter of the world's under- 25 populations. To leverage on its youth demography, Africa can become a top global player if investment is channeled to create quality STEM education. STEM education is the fulcrum of an innovative and highly productive future workforce, which is imperative to the survival of any economy. Massifying STEM education has been reputed to be a pathway to a brighter future, and it is a veritable tool for opening up a wide range of interesting, and exciting career opportunities (central office of information, 2008). To develop a strong base of scientists needed for rapid development on the continent, Africa needs to massif STEM education. STEM strategies are designed for developing a strong team of scientist, engineers, technologists and mathematicians (Department for Education and Skills, 2006).. Studies reveal that in the United States of America, there is an increase in the number of jobs that require STEM skills, creating a need to have world class STEM workforce to meet the challenges of the 21century. (The White House, 2009).

A research by NRC (2009) noted that the primary builder of the future economy is STEM education, and it is a stable source of jobs brought about by innovations in science and engineering. Science, mathematics, engineering and technology, will increase the number of jobs available at a general level (lacey T.A and Wright B, 2009). Since all societal processes involve a fraction of science, there is a need to massify STEM education. According to (national governor's association, 2007 employers in many industries decry the lack of needed mathematics, computer, and problem solving skills that are vital for success on the job, predominantly among international students

There are huge demands for STEM inclined employees currently, and at least 16 of 20 applicants with the highest future goals in the next decade will be STEM related. This emphasizes the importance of STEM education as a vital tool for growth and development, which can only be harnessed by intensifying effort and increasing enrollment in these fields. To keep up with the realities of the $21^{\text {st }}$ century, STEM education is vital and there is a need to increase STEM literacy for all students, including students who are not involved with STEM related courses. The need to think and make decisions in the $21^{\text {st }}$ century requires scientific and technological understanding. To understand current issues that affect the world in the $21^{\text {st }}$ century, such as drastic changes in the environment, health and energy sectors, scientific knowledge is of great importance. Massifying STEM education will help all students to better prepare to face the challenges of a science and technology based economy.

\section{THE TRANSFORMATION OF STEM EDUCATION IN AFRICA THROUGH MASSIFICATION}

Nations with advanced scientific knowledge to inform their positions on economic development and growth enjoy a progressive economy. Africa's position on the international sphere is directly dependent on this kind of knowledge, which can only be attained through grooming a vibrant populace with capabilities in STEM fields. The lack of a capable STEM workforce implies that Africa will continue to transfer it's major resources to expatriate countries, either through brain drain, or in order to construct and maintain public infrastructures on the continent, since they cannot do so themselves(Khumbah, 2018). Mohamedbhai writes

Massification involves changes in the composition, character 
and aspirations of students ( including increasing gender parity and admission of great numbers of lower, middle class, and working class students); changes in the size of institutions and new Institutional types including private providers; pressures on the infrastructure and financial and human resources of existing public higher education institutions; changes in curriculum and modes of delivery; changes in higher education funding typically involving the introduction of some forms of cost sharing; and changes in the academic workforce such as an increasing casualisation of teaching staff. (Mohamedbhai, 2014 as cited in Luesher, 2016, p.32).

Inferring from Mohamedbhai's assertion and other findings in the course of this research, this study posits that transforming STEM education in Africa through massification boarders on three key factors; Access, Quality, and Relevance.

Increasing the enrolment of African students into STEM fields will increase if access is made easy. In Africa, access to STEM education is difficult and uneven due to a myriad of factors championed by lack of funding. This study asserts that improvements can be made, by broadening participation in STEM fields. First, Access is hindered due to lack of awareness. African students believe the perceived notion that STEM fields are quite complex, and attaining success in these subjects are difficult. Most students just want to achieve high grades, and they are turned off STEM subjects because of this perception. They prefer to take art subjects or undertake majors they are sure they will excel and obtain high grades from. Some students loose interest because their classrooms are not equipped with modern technological resources that enhance, and ensure ease of learning of these STEM subjects, which makes learning uninteresting and difficult. To pique the interest of African students in these fields, they need to be made aware of its individual and societal benefits, especially in this era driven by technological advancements. Infrastructures for learning in STEM fields should be made adequate, thereby encouraging students to explore these fields, and this requires adequate funding. Secondly, the teaching and learning process for STEM education can be done in African languages as opposed to English language. This will enhance understanding, and increase innovation and contribution from Africa's mass population as learning is made easier. Lastly, the women and children population should not be left out. It is important to ensure that children have access to STEM education in their early years. Introducing STEM to kids will encourage creativity and critical thinking; it will also develop their passion for STEM fields, encouraging them to pursue STEM majors. The notion that women do not do well in STEM fields should be eradicated, and all gender disparity in these fields should be eliminated by enhancing female participation in science and technology.

Kigotho (2015) reveals that while research output in Africa has grown overtime, research in STEM in most countries continued to decline at the rate of $0.2 \%$ annually since 2002 . This was adjudged to result from the low quality of basic education in science and mathematics. Research has revealed the cause of low quality STEM education in Africa to be lack of funds, unqualified teachers, incessant strikes and unavailability of required resources. Tikly et al. (2018) concurs as they opine that the systemic challenges hindering quality STEM education in Africa includes lack of qualified STEM teachers, high pupil ratios, unavailability of resources, and outdated curricula. The issue of unqualified teachers arises because as enrollment increases, the demand for teachers will also increase. Due to the shortage of professionals with sufficient knowledge in STEM fields, unqualified teachers are employed to fill the gap. Teachers should be well trained to handle STEM portfolios by using training programs and projects to perfectly hone their skills. The STEM career field should be made more attractive to prevent capable hands from delving into other rewarding careers. If Africa has more trained teachers in STEM fields, the issue of high pupil teacher ratios will become history, making STEM classrooms more engaging as students will be evenly distributed. STEM subjects require hands on scientific equipment and learning resources. Teachers should not be made to rely on theoretical explanations, as this discourages students from developing creative and critical thinking skills, communication and collaborative skills, which are enhanced by teamwork. STEM curricula across the globe have been updated to adapt to the current global changes in technology, this should be the same for Africa.

Most African institutions still use outdated curricula overloaded with old information that are obsolete. The STEM curricula should be adjusted to reflect the current global changes in STEM fields (Tikly et al., 2018). This curriculum should be embedded in real-world contexts because, the right STEM curricula builds transferable skills, and helps students to understand the relevance of science to their future. This new curriculum will help them brainstorm, and come up with innovative solutions to issues in their locality. A relevant STEM curriculum will promote problem based learning, inquiry based learning enhance creativity, develop problem solving skills, and equip students with the required skills for real life situations. If the physical, human, and financial resources required are adequate, massification of STEM education in Africa will yield positive results (Delacy, 2017; Mohamedbhai, 2017).

\section{CONCLUSION AND RECOMMENDATION}

It is notable to bear in mind that the world in which we live today is a discovery, and knowledge-driven world. The fourth industrial revolution is on course, and science and technology have come to occupy a pivotal place, as sources of economic growth and social well-being. Innovation through scientific activities have led to dramatic increase in agricultural productivity, the creation of new industries with new materials and technologies, a change in communication and information technology, and improvements in health and quality of life. This is in line with the findings of Lee JR (2017) who maintains that agricultural industries are poised to transit into high-tech industries, using advanced technology such as artificial intelligence and big data. From all indications, massification of STEM education in Africa will lead to an increase in the enrollment of students into STEM fields in the primary, secondary, and tertiary levels of education on the continent. This will subsequently transform and provide the level of manpower needed for the growth, and development of 
Africa as a continent. As revealed in this study, STEM education is vital for ensuring economic transformation and should therefore be massified. Several challenges hampering the massification of STEM education including the unavailability of qualified STEM teachers, high pupil -teacher ratios, unavailability of required resources, and outdated curricula were revealed. This study recommends the renewal and intensification of focus on STEM education in Africa in order to ensure economic prosperity. This can be achieved through the massification of STEM education ,creating access to STEM fields, improving the quality of STEM education obtainable, and ensuring it's relevance to real-life African situations. Finally, the successful implementation of innovative strategies aimed at massification begs the active involvement of all stakeholders; policy makers, governments, management, staff, students of higher education institutions, and the general populace, necessary for maintaining a change in the educational trajectory of Africa. Creating STEM education and research strategy centers should be encouraged. This involves identifying selected higher education institutions, and investing in them as national, and continental assets. Secondary schools can also be involved by grooming capable and motivated students in selected STEM -focused secondary schools, preparing them to major in STEM fields at these selected higher education institutions. Children should not also be left out, as STEM education should be made available to all in Africa, regardless of age and gender

\section{REFERENCES}

[1] African American Institute. (2015). State of Education in Africa Report 2015. Retrieved from www.aaionline.org/wp-content/uploads/2015/09/AAISOE-report-2015-final.pdf

[2] African Union Commission, (2014), Science, Technology and Innovation Strategy for Africa https://au.int/sites/default/files/newsevents/workingdoc uments/33178-wd-stisa-english_-_final.pdf.

[3] Autor DH, Katz LF, Kearney MS. (2008).Trends in US wage inequality: Revising the Revisionists. Rev econ and stat. 90:300-23

[4] Babaci-Wilhite, Z., Geo-Jaja, M.A., \& Azaiki, S. ( 2016). Human Rights in Development Aid for STEM Education in Nigeria Languages. In Human Rights in Language and STEM Education, by Babaci-Wilhite Zehilia. Springer, 2016. ISBN 946300405X

[5] Breiner, J. M., Harkness, S. S., Johnson, C.C., \& Koehler, C. M. (2012). What is STEM? A Discussion About Conceptions of STEM Education and Partnerships. School Science and Mathematics. 112(1):3-11

[6] Brennan, J. (2004). The Social Role of the Contemporary University: Contradictions, Boundaries and Change," Ten Years On: Changing Education in a Changing World, Center for Higher Education Research and Information, Milton Keynes, The Open University.

[7] Burnett, N., \& Jayaram, S. (2012). Innovative
Secondary Education for Skills Enhancement: Skills for Employability in Africa and Asia. Washington, DC: Results for Development Institute. Retrieved from https://www.r4d.org/.../InnovativeSecondaryEducation SkillsEnhancement-PhaseI-Syn..

[8] Chalmers, C., Carter, M., Cooper, T. \& Nason, R.(2017). Implementing "Big Ideas" to Advance the Teacher and Learning of Science, Technology, Engineering, and Mathematics (STEM). International Journal of Science and Mathematics Education, 15 (1), 25-43. doi:10.1007/s10763-017-9799-1

[9] Department for Education and Skills. (2006) STEM Programme Report. London: Author. Central Office of Information (2008) Retrieved from http://www.coi.gov.uk/press.php?release $=217$ on Feb $1,2010$.

[10] Delacy, M. (2017). 5 Resons You Shouldn't Ignore STEM Curriculum. KnowAtom Blog- Insights to STEM Curriculum and NGSS. Retrieved From: http://www.knowatom.com

[11] Durik, A.M., Hulleman, C.S. \& Harackiewicz, J. M., (2015). One Size Fits Some: Instructional Enhancements to Promote Interest. Interest in Mathematics and Science Learning, 49-62.

[12] Fred, S. (2016). Great Leaders Aren't Born-They`re Made and Africa is Showing Us How. World economic forum.

[13] Gonzalez, H. B., Kuenzi, J. J. (2012). (Congressional Research Service 7-5700). Science, Technology, Engineering and Mathematics (STEM) Education: A Primer. http://www.fas.org/sgp/crs/misc/R42641.pdf

[14] Good Governance Africa. (2012) Africa's Natural Resources: If WeAare so Rich, Why Are We So Poor? The Journal of Good Governance Africa 1-35.

[15] Guri-Rosenblit, S., \& Sebkova, H. (2004). Diversification of Higher Education Systems: Patterns, Trends and Impacts, UNESCO Forum Occasional Forum Series, Paper No. 6 - "Diversification of Higher Education and the Changing Role of Knowledge and Research", 40-69.

[16] Honey M, Pearson G, Schweingruber H, (2014). Editors. STEM Integration in k-12 Education: Status, Prospects and an Agenda for Research. National academies press.

[17] Hornby, D. J., \& Oman, R. (2014). Massification in Higher Education :Large Classes and Student Learning. Higher Education 67 (6):7-11

[18] Iksan, Z. (2009). Promoting Cooperative Learning in Science and Mathematics Education: A Malaysian Perspective. Colección Digital Eudoxus, (7).

[19] Kariwo, M., Gounko, T., \& Nungu, M. (2014). A Comparative Analysis of Higher Education Systems: Issues, Challenges and Dilemmas. Sense publishers, Rotterdam - The Netherlands.

[20] Khumbah, N. (2018). STEM Education and African Development. African Policy Review; Analysis Education and Youth Development. Retrieved From : 
http://www.africapolicyreview.com

[21] Kigotho, W. (2015). STEM Research in Sub Sahara Declining-World Bank. University World News, Published 11 December, 2015. Retrieved From: http://www.universityworldnews.com

[22] Kurennoy, V. (2011). Bastard of modern. About the current university crisis. New Literature Review, 3.

[23] Lacey, T.A., \& Wright, B. (2009). Occupational employment projections to 2018. Monthly Labor Review, 132(11), 82-123. Available at: http://www.bls.gov/opub/mlr/2009/11/art5full.pdf.

[24] launches-educate-innovate-campaign-excellencescience-technology-en on Feb 1, 2010

[25] Lee, J. R. (2007) The Fourth Industrial Revolution and Future Agriculture. Rep. of Korea: Science and Technology Policy Institute.; 200 ed Management, 18 (2), 1-15.

[26] Lusher, T. M.(2016). Student Representation in a Context of Democratisation and Massification in Africa: Analytical Approaches, Theoretical Perspectives and \#Rhodes Must Fall. In Student Politics in Africa: Representation and Activism by Lueschr, T.M., \& Klemencic, M., \& Jowi, J.O.

[27] McDonald, C.V. (2016). STEM Education: A review of the Contribution of the Disciplines of Science, Technology, Engineering and Mathematics. Scince Education International, 27(4): 530-569

[28] Mac Gregory, K. (2014). The Massification of Higher Education in South Africa. University World News, Published 21 June, 2014. Retrieved From: http://www.universityworldnews.com

[29] Mcguinness, W. (2018). The Benefits and the Limitations of Machine Learning in Education. Getting Smart, February, 2018. Retrieved From : http://www.gettingsmart.com/2018/02/the-benefits.

[30] Marginson, S. (2017). Elite, Mass, and HighParticipation Higher Education. Encyclopedia of International Higher Education Systems and Institutions, 1 - 8. DOI 10.1007/978-94-017-95531_50-1】

[31] Mohamedbhai, G. (2014). Massification in Higher Education Institutions in Africa: Causes, Consequences, and Responses. International Journal of African Higher Education, 1 (1): 59-83

[32] Mohamedbhai, G. (2017). Institutional Massification in African a Universities. The World View : A Blog From the Center for International High Education, Published 17 May, 2017. Retrieved From : http://www.insidehighered.com

[33] Merton RK.(1942). The Normative Structure of Science. In: Merton R, editor. The sociology of Science: Theoretical and Empirical Investigations. Chicago: University of Chicago Press. Pp 267-78

[34] National academy of Science(NAS). National Academy of Engineering (NAE) and Institute of Medicine (IM). (2007). Rising Above the Gathering Storm: Energizing and Employing America for a brighter future.
Washington DC: National Academies press

[35] National Governors Association. (2007). Innovation America: A final report. Washington, DC: Author. Available at: http://www.nga.org/Files/pdf/0707innovationfinal. pdf.

[36] National Research Council. (2009a). Engineering in $K$ 12 education: Understanding the Status and Improving the Prospects. Washington, DC: The National Academies Press.

[37] Next Generation Science standards (NGSS). 2015. http://www.nextgenscience.org/

[38] Ohize, E. J. (2017). Repositioning Science, Technology, Engineering and Mathematics Education for Economic Recovery in Nigeria. Conference Proceedings. "Reposition Science, Technology, Engineering \& Mathematics (STEM) Education for Economic Recovery in Nigeria." Kontagora, Niger State. Retrieve from www.sciencesfcekg.sch.ng/downloads/ConferenceProc eedings_11th_2017.pdf

[39] Okeke, R.N., Babalola, C.P., Byarugaba, D.K., Djimde, A., \& Osoniyi, O.R. (2016). Broadening Participation in the Sciences with and From Africa: Purpose, Challenges, and Prospects. CBE Life Sciences Education, 16 (2): es2

[40] Ostler, E. (2012). 21st century STEM Education: A Tactical Model for Long-Range Success. International Journal of Applied Science and Technology, 2(1).

[41] Penprase, B.E.(2018). The Fourth Industrial Revolution and Higher Education. Singapore; Palgrave Macmillian. Retrieved From: http://www.link.springer.com

[42] Phillip L.Clay. (2016). Its Africas Time to Rise, lets End our Academic Isolation. The Guardian

[43] President's Council of Advisors on Science and Technology. (2010).

[44] Quintero-Re, L. (2011). TheImpact of DemandAbsorbing Universities in Mexico's Higher Education System. Reflecting Education, 7(1), 55-66.

[45] Republic of Kenya (1988). Education and Manpower Training for the Next Decade. Nairobi: Government Printer.

[46] Richard, M.O. (2016). Implications of Massification of Higher Education in Kenya Public Universities: A Case of Kenyatta University. Retrieved From: http://www.academia.edu

[47] Rothwell J. (2013). The hidden STEM Economy. Brookings institute. http://www.brookings.edu/research/reports/2013/06/10stem-economy-rothwell.

[48] Sanders, M. E. (2008). Stem, Stem education, stemmania.

[49] Sarah, B. (2016). Special Report: the World's Youngest Populations. Euromonitor International. 13

[50] Sawyer, A. (2004). Challenges Facing African Universities. Available: http://www.rci.rutgers.edu 
[51] Schilero, D. (2013). Diversification and Development of the UAE's Economy. Munich Personal RePEc Archive, Paper No. 47089, Posted 20 May, 2013.

[52] Siekmann, G., \& Korbel, P. (2016). Defining 'STEM' Skills: Review and Synthesis of the Literature. Support Document 2, NCVER, Adelaide.

[53] Srikanthan, G. (ND). Developing a Model for Quality in Higher Education. Bundoora, Victoria, Australia

[54] The White House. (2010) Retrieved from http://www.whitehouse.gov/the-pressoffice/presidentobama-

[55] Tikly, L., Joubert, M., Barrett, A.M., Bainton, D., Cameron, L., \& Doyle, H. (2018). Supporting Secondary School STEM Education for Sustainable Development in Africa. Bristol Working Papers in Education. Working Paper\# 05/2018. Retrieved From: http://www.btistol.ac.uk

[56] Trow, M. (1974). Problems in the Transition from Elite to Mass Higher Education, in: OECD (ed.): Policies for Higher Education. OECD General Report - Paris, 51101.

[57] Trow, M. (2000). From Mass Higher Education to Universal Access: The American Advantage. Research and Occasional Paper Series, Center for Studies in Higher Education. UC Berkeley.

[58] Trow, M. (2006). Reflections on the Transition from Elite to Mass to Universal Access: Forms and Phases of Higher Education in Modern Societies Since WWII. In: Altbach P., Forest, J. (Eds.). International Handbook of Higher Education. Dordrecht: Springer, Vol. 1, pp.243280

[59] UNESCO. (2007a). Education for All. Global Monitoring Report. Paris.

[60] UNESCO. (2007b). The Virtual University: Models and Messages. Retrieved from http://www.unesco.org/iiep/virtualuniversity/home.php

[61] Voogt, J., \& Roblin, N. P. (2012). A Comparative Analysis of International Frameworks for 21st Century Competences: Implications for National Curriculum Policies. Journal of Curriculum Studies, 44(3), 299321.

[62] Wang, M-T., Chow, A., Degol, J.L., \& Eccles, J. S., (2017). Does Everyone's Motivational Beliefs About Physical Science Decline in Secondary School: Heterogeneity of Adolescents' Achievement Motivation Trajectories in Physics and Chemistry. Journal of Youth and Adolescence, 46(8), 1821-1838

[63] Watkins, A., \& Ehst, M. (2008). Science, Technology, and Innovation: Capacity Building for Sustainable and Poverty Reduction. The World Bank.

[64] Williams, J. (2011). STEM Education: Proceed With Caution. Design and Technology Education: An International Journal, 16(1).

[65] Wilson Wyner, J.S., Bridgeland, J.M., and Diiulio, J.J. (2007). The Achievement Trap: How America is Failing Millions of High-Achieving Students from Lower Income Families. A Report by the Jack Kent
Cooke Foundation and Civic Enterprises. Available at: http://www.jkcf.org/assets/ files/0000/0084/Achievement_Trap.pdf.

[66] Wilson, B. (1996). Quality in Universities: Sir Robert Menzies Oration. Journal of Higher Education Policy and

[67] World Economic Forum. (2016). Mastering the Fourth Industrial Revolution. January, 2016. Retrieved From: http://www.ww3.weforum.org

[68] World Economic Forum. (2018). The Future of Jobs Report 2018. Published 17 September, 2018. Retrieved From: http://www.weforum.org

[69] Xie, Y., Fang, M., \& Shauman, K. (2015). STEM Education. The Annual Review of Sociology, 41(19): $1-19$

[70] Xie, Y., Killewald, A. A. (2012). Is American Science in Decline? Cambridge Harvard University Press

[71] Xie, Y., Shauman, K. A. (2003). Women in Science: Career Processes and Outcomes. Cambridge, MA: Harvard University Press

[72] Xie Y. (1989). The Process of Becoming Scientist. Department of Sociology, the University of WisconsinMadison: Unpublished dissertation. 